\title{
Effect of Tannin Containing Herbal Feed Additives on Ruminal Nutrient Utilization and Methane Mitigation - A Review
}

\author{
Prabhjot Kaur Sidhu* and Anant Simran Singh
}

Khalsa College of Veterinary and Animal Sciences, Amritsar, Punjab, India

*Corresponding author

\section{A B S T R A C T}

Keywords

Tannin,

Herbal feed

additives,

Ruminal nutrient,

Methane mitigation

Article Info

Accepted:

26 November 2019

Available Online:

10 December 2019
Ruminant livestock constitute worldwide the most important source of anthropogenic emissions of methane. There are two main factors influencing global warming change, an increase in greenhouse gas emissions and depletion of the ozone layer. Methane is associated with both factors. Ruminants (dairy, beef, goats, and sheep) are the main contributors to $\mathrm{CH}_{4}$ production. Their $\mathrm{CH}_{4}$ production is a natural and inevitable outcome of rumen fermentation. To overcome this situation, the most promising way to mitigate enteric methane production is either through dietary manipulation by supplementing diet with herbal feed additives containing tannins as an active principal. Tannins are polyphenolic secondary plant compounds that they do not actively involved in primary biochemical processes such as plant growth, development and reproduction but have been shown to affect microbial activity to impact fermentation, protein degradation and methane production. There is a need for identifying feed additives with the potential to modify rumen fermentation for enhancing the efficiency of utilization of feed energy while decreasing rumen methanogenesis. However amount of tannins to be provided so as to increase nutrient digestibility needs further investigation as there is very fine line between positive and negative effects of tannins.

\section{Introduction}

Increasing attention has been placed on greenhouse gas (GHG) emissions in recent years with deteriorating scenario of global warming (O'Mara, 2011). Deforestation is a major contributor towards increased carbon accumulation into atmosphere causing direct $18 \%$ increase in emissions. Large scale changes such as deforestation, soil erosion or machine-intensive farming methods all are partially or wholly culprits for the current scenario. Soil loss, and its associated impacts, is one of the most important (yet probably the least well-known) of today's environmental problems. Talking about livestock sector approximately $7-18 \%$ of the global GHG emission comes from enteric methane production. Globally, about 80-115 Tg methane equivalent to $15-20 \%$ of total anthropogenic methane is produced/annum by domestic livestock (Houghton et al., 2001). 
An estimated methane emission per year per animal is as following

\begin{tabular}{|ccc|} 
S. No. & Species & $\begin{array}{c}\text { Methane release } \\
\text { (kg/year) }\end{array}$ \\
\hline $\mathbf{1}$ & $\begin{array}{c}\text { Western } \\
\text { cattle }\end{array}$ & 120 \\
$\mathbf{2}$ & $\begin{array}{c}\text { Eastern } \\
\text { cattle }\end{array}$ & 60 \\
& Sheep & 8 \\
$\mathbf{3}$ & Pig & 1.5 \\
$\mathbf{4}$ & Chicken & 0.015 \\
$\mathbf{5}$ & Human & 0.8 \\
$\mathbf{6}$ & &
\end{tabular}

Many techniques can be used to decrease enteric methane production by ruminants involving use of various chemicals and defaunation however usage of nutritional metabolites remains most promising and feasible technique. Number of studies has been conducted to assess the potential of plant secondary metabolites as natural manipulating agents for ruminal fermentation (Wallace et al., 2002). Plant secondary compounds, such as tannins have been studied both for their nutritional effects (positive or negative) on animal productivity and health and for their anti-methanogenic properties. However, the methane mitigating effects of tannins was found to be inconsistent (Beauchemin et al., 2008; Makkar et al., 2003) as it further depends upon dose, the source and the structure of the tannins. A lot of studies and description among effect of Condensed tannins in human foods and beverages, including wine, berries and cocoa, have been made (Cheyneir, 2012) however their effect among forages and other but less is known about the CTs found in natural forages. Though earlier studies focussed upon decreased nitrogen utilization in presence of tannins (decreased crude protein digestibility) however recent studies are more inclined towards beneficial effects of tannins on domestic animals (Hanley, 1992).

\section{Methane formation}

Farmed ruminants are the largest source of anthropogenic methane emissions globally. The methanogenic archaea responsible for these emissions use molecular hydrogen $\left(\mathrm{H}_{2}\right)$, produced during bacterial and eukaryotic carbohydrate fermentation, as their primary energy source. The mixed rumen microbiota has the ability to digest plant fiber unavailable for humans and produce fermentation products and microbial biomass that the host animal absorbs and converts to products useful for humans. Methane $\left(\mathrm{CH}_{4}\right)$ is the main sink of metabolic hydrogen $[(\mathrm{H})]$ in rumen fermentation. Metabolism of carbohydrates by the fermentative microbiota of bacteria, protozoa and fungi reduces co-factors, which are re-oxidized mostly by transferring electrons to protons. Dihydrogen $\left(\mathrm{H}_{2}\right)$ so formed is transferred to methanogenic Archaea, which utilize it to reduce carbon dioxide $\left(\mathrm{CO}_{2}\right)$ to $\mathrm{CH}_{4}$ (Russel et al., 1997). Energy lost as $\mathrm{CH}_{4}$ is an inefficiency in the conversion of digestible energy (DE) to metabolizable energy (ME), because $\mathrm{CH}_{4}$ is formed from organic matter (OM) digested and fermented in the rumen and hindgut (Hill et al., 2016).

\section{Tannins}

Tannins are a heterogeneous group of watersoluble polyphenolic compounds of high molecular weight (500-3000 Daltons)withasmanyas20hydroxylgroups-and are present in plants, foods and beverages where they provides protection against a wide range of biotic and abiotic stressors (de Jesus et al., 2012). Being phenolic compounds, tannins are chemically reactive and form inter- and intramolecular hydrogen bonds that are able to interact with, and precipitate macromolecules, such as proteins and carbohydrates providing astringent taste of many fruits and vegetables (de Jesus et al., 2012; Lamy et al., 2016). 
Tannins exert several pharmacological effects, including antioxidant and free radical scavenging activity as well as antimicrobial, anti-cancer, anti-nutritional and cardioprotective properties. They also seem to exert beneficial effects on metabolic disorders and prevent the onset of several oxidative stressrelated diseases. Although the bioavailability and pharmacokinetic data for these phytochemicals are still sparse, gut absorption of these compounds seems to be inversely correlated with the degree of polymerization. Tannins can be classified into two groups: hydrolysable tannins and condensed tannins (also named catechin tannins or proanthocyanidins). Hydrolysable tannins can be further divided into gallotannins, which provide sugar and gallic acid on hydrolysis, and ellagitannins, which on hydrolysis do not yield just sugar and gallic acid but also ellagic acid (see Lamy et al., 2016)

\section{Effects of tannins on digestibility}

Tannins can show many diverse effects like improved nitrogen utilization (min et al., 2003), improved meat and milk quality (Rochfort et al., 2004) and also increased wool production in sheep (Doran Browne et al., 2015). In addition to above effects like decreased intestinal nematode proliferation (Naumann et al., 2017), reduced chances of bloat (Muller-haurvey, 2006) and reduction in methane production during digestion have been obserevd. Calliandra calothyrsus and Fleminga macrophylla both rich in tannins were used by Tiemann et al., 2008 and replaced herbaceous high-quality legume (Vigna unguiculata) either $1 / 3$ or $2 / 3$, respectively, of a in a diet composed of the tropical grass Brachiaria brizantha and Vigna in a ratio of $0.55: 0.45$ and Brachiaria-only diet served as the negative control. Increased tannin concentration produced a linear decrease in OMD, NDF \& ADF digestibilities with fecal $\mathrm{N}$ distribution on higher side as compared to urinary Bhatta et al., (2013) fed tannins from Mimosa sp. to goats while keeping ruminal fermentation, energy partitioning and methanogenesis into consideration. The control fed with $1 \mathrm{~kg}$ of basal diet to the control which was replaced with 0.025 and $0.050 \mathrm{~kg}$ of Mimosa tannins making treatment groups as $\mathrm{T}_{1}$ (low tannin) and $\mathrm{T}_{2}$ (High tannin). Total contents (DM basis) of tannins (hydrolysable and condensed) in the control, low- and hightannin diets were $0,2.8$ and $5.6 \mathrm{~g} / \mathrm{kg} \mathrm{DM}$, respectively. Among No changes were observed in GE intake and DM intake. Digestibilities of all dietary components in the high-tannin diet were lower $(P<0.05)$ than low-tannin and control diets. In a study conducted by Aboyogae et al., 2019 used different sources of hydrolysable tannins (chestnut CN, Tannic acid, TA and gallic acid GA) to observe their effects on apparent total tract digestibility, methane production and nitrogen utilization in beef cattle fed with alfalfa silage as basal diet having $(19.8 \% \mathrm{CP})$ was formed using alfalfa silage $75 \%$, barley silage $20 \%$ and 5\% supplement on DM basis. No change in DM and nutrient intake was observed among treatment and control however CP digestibility was decreased for TA and CN compared with control and GA treatments (63.1 vs. 69.0\%; $P<0.001)$. Similarly as per the previous studies discussed $\mathrm{N}$ excreted in faeces increased for tannic acid and chestnut and decreased the proportion of $\mathrm{N}$ excreted in urine as compared to Gallic acid and control (43.9\% vs. $37.8 \%$ and $56.1 \%$ vs. $62.2 \%$; respectively; $P<0.001)$. Mezommo et al., 2018 evaluated changes in dietary intake on replacing SM (soyabean meal) with SMT (soya bean meal treated with tannins) among young cattle fed with high concentrate diets. The basal diet contained around $7.5 \%$ of SM which was replaced by SMT with proportions of $(0 \%, 33 \%, 66 \%$ or $100 \%)$. Ruminal and intestinal digestibility of crude protein each showed a linear decrease with increased 
amount of tannins and saponins. However there was a positive linear relation seen between ruminal undegraded protein and amount of soya bean meal tannins.

\section{Effects of tannins on methanogenesis}

Ruminant animals contribute significantly to the production of methane during rumination and this greenhouse gas contributes to the increase of global temperatures (Jayanegara, 2012). About 2-8\% of GE (Johnson kA, 1995) is used in production of methane leading to decreased productivity thus tannins can be used for both, increasing productivity and environment friendly dairy farming. Tanninrich plants diminish ruminal methane production both in vitro (Bhatta et al., 2013; Tiemann, 2008) and in vivo (RamirezRestrepo, 2005, Bhatta et al., 2013, Moreira, 2013). Adding crude tannin to tannin-free forage also reduces methane production (Pellikaan, 2011). Nauman et al., 2013 conducted an in vitro study which showed correlation of $\mathrm{R}^{2}$ of $0.44 \%$ suggesting reduction in methane in presence of condensed tannins as compared to control. Robbins et al., 1987 were one of the first researchers to generate equations to predict digestible protein and digestible dry matter on the basis of laboratory analytical techniques which were further used for in vivo digestion trials by Hanley et al., 1992 using black tailed deer (Odocoileus hemionussitkensis). Keeping crude protein digestibility and protein precipitating capacity in consideration tannins from seven different forages were fed which showed their effectiveness in digestion and nutritional value of the tannin rich plants (Hanley et al., 1992). A reduction in methane per day per unit feed and energy intake emission was observed on addition of tannin rich diet in the feed of lambs however reduction in organic matter and fibre digestion could be one of the primary reason (Hanley et al., 1992). Hassanat et al., (2013) kept positive and negative control and showed positive effects on energy and protein utilization through IVGPT. Effect of condensed tannins of acacia and quebracho and hydrolysable tannins of chestnut and valonea tannins on rumen microbial fermentation was observed using IVGPT which showed a linear decrease in In vitro gas production and total volatile fatty acid (VFA) concentration with increased tannin concentration. It was observed that valonea tannins $\geq 50 \mathrm{~g} \mathrm{~kg}^{-1}$ or quebracho tannins at $\geq 100 \mathrm{~g} \mathrm{~kg}^{-1}$ resulted in a decrease (up to $40 \%$ ) in methane $\left(\mathrm{CH}_{4}\right)$ production compared with the control. Valonea tannins were the only tannin source that reduced $(-11 \%) \mathrm{CH}_{4}$ production at $50 \mathrm{~g} \mathrm{~kg}^{-1}$ without affecting VFA concentration. Ruminal protein degradation was hypothesized as ammonia $\left(\mathrm{NH}_{3}\right)$ and branched- chain VFA concentrations was observed on addition of tannins. As per the positive control, Monensin was added which showed reduction in methane production (-37\%) and $\mathrm{NH}_{3}$ concentration $(-20 \%)$ without affecting total VFA concentration. On feeding Mimosa tannins Bhatta et al., 2013 found $\mathrm{CH}_{4}$ energy excretion was $0.98,0.87$ and $0.76 \mathrm{MJ} / \mathrm{d}$ for goats on control, low- and high-tannin diets, respectively, whereas their corresponding values for $\mathrm{CH}_{4}$ conversion ratio were $0 \cdot 079$, 0.069 and 0.060 of GE intake suggesting decrease in methane production even on smaller amount of tannins added. In another In vitro study by Hatew et al., 2015 used Sainfonin (a non-bloating temperate legume) containing large amount of condensed tannins with an aim of identifying promising accessions for future investigations. Fermentation kinetics (i.e. parameters describing the shape of the gas production curve and half- time gas production) for $\mathrm{CH}_{4}$ production were influenced by accession $(P \leq$ 0.038). In a study conducted by Aboyogae et al., (2019) concluded that both tannic acid and chestnut had no effects on methane production and yet decreased CP 
digestibility and lead to shifting of urinary $\mathrm{N}$ to faecal $\mathrm{N}$ whereas GA (i.e., HT subunit) decreased $\mathrm{CH}_{4}$ production and decreased the proportion of urea $\mathrm{N}$ in urinary $\mathrm{N}$ in beef cattle without affecting $\mathrm{CP}$ digestibility making Gallic acid a promising product so as to reduce methane production without affecting CP digestibility. Isabel Cristina et al., 2019 evaluated effects of adding increasing levels of ground pods of Enterolobium cyclocarpum which were rich in both tannins and saponins mixed with foliage of Gliricidia sepiumon emissions of ruminal methane, volatile fatty acid production and rumen microbial population (Fig. 1 and 2).

Fig.1

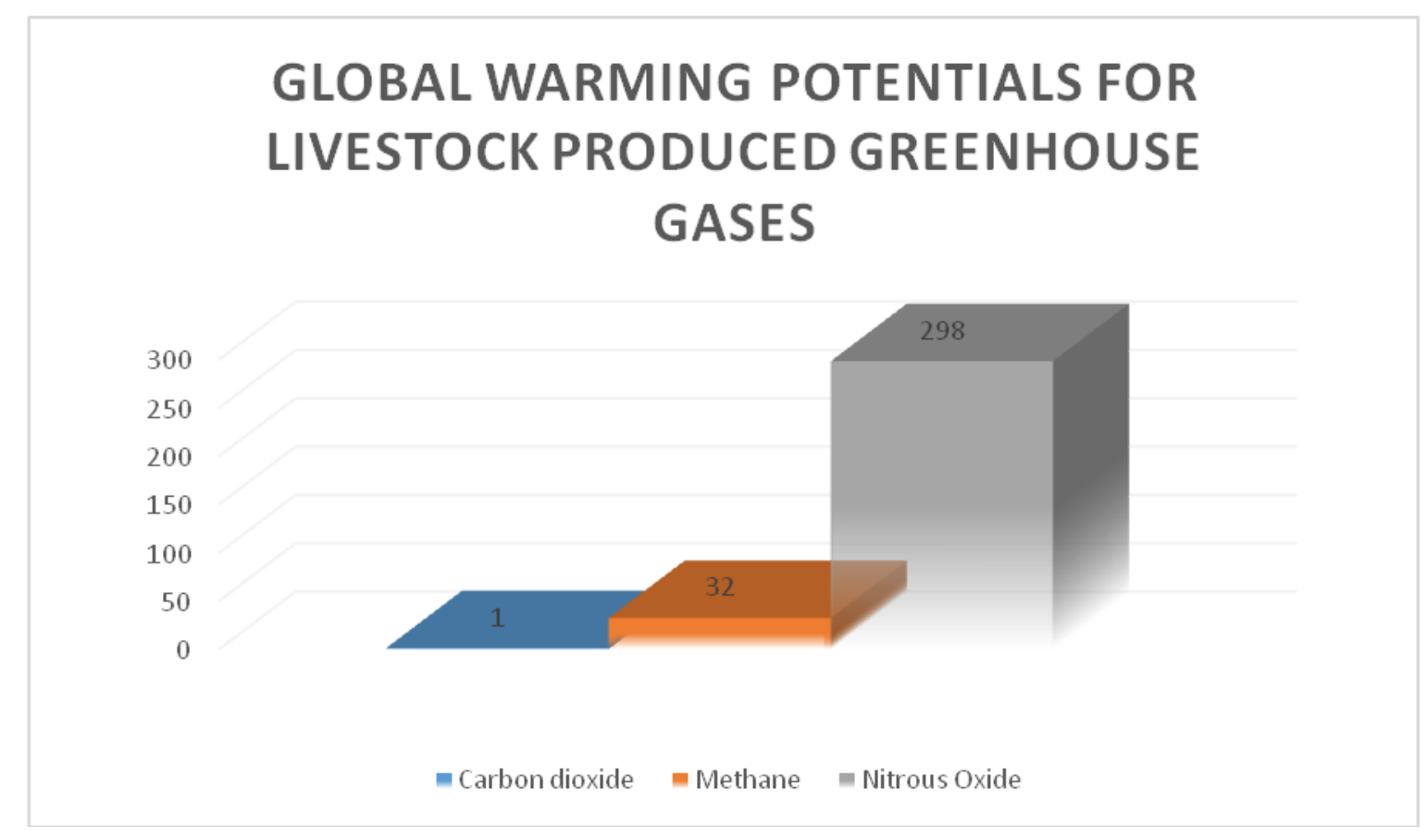

Fig.2

\section{PERCENT REDUCTIONS IN METHANE EMISSIONS FROM RUMINANTS}

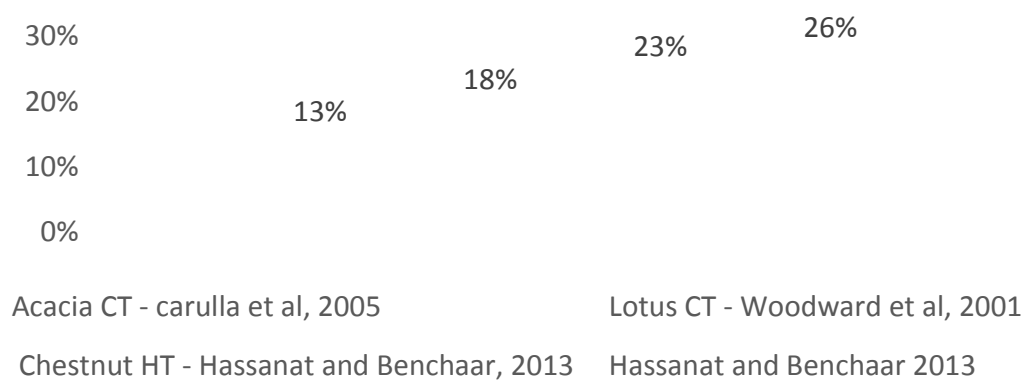


Methane production, expressed on basis to digestible dry matter intake (DDMI), ranged between 43.22 and $49.94 \mathrm{~g} / \mathrm{kg}$ DDMI $(\mathrm{P}=0.131)$ and when $\mathrm{CH}_{4}$ was related to digestible $\mathrm{CP}$ (347 vs. $413 \mathrm{~g} \mathrm{CH}_{4} / \mathrm{kg} \mathrm{DCP}$ ) or annual weight gains $\left(0.30 v s .0 .38 \mathrm{~kg} \mathrm{CH}_{4} / \mathrm{kg}\right.$ weight gain, $\mathrm{P}<0.001)$ there were differences between the E. cyclocarpum mixed with $G$. sepium rations compared to the control treatment, respectively. However no changes in ruminal methanogens and total protozoa were observed by increasing level of condensed tannins and saponins $(\mathrm{P}>0.05)$. When G. sepium foliage mixed with $E$. cyclocarpum pods substituted in the rationupto $15-30 \%$, a decrease in annual methane emissions per unit product, without affecting dry matter intake or rumen microbial population was observed suggesting beneficial effects of antinutritional factors like tannins and saponins. Mezommo et al., 2018 evaluated changes in dietary intake on replacing SM (soyabean meal) with SMT (soya bean meal treated with tannins) among young cattle fed with high concentrate diets. The basal diet contained around $7.5 \%$ of SM which was replaced by SMT with proportions of $(0 \%, 33 \%, 66 \%$ or $100 \%)$. However mezommo et al., found no relationship between methane emissions and amount of tannin treated soyabean meal. Toral et al., 2019 used different combinations of tannins using IVGPT and found synergistic actions between them as individually they did not show any changes among nutrient utilization and methane mitigation. Rumen liquor from cannulated ewe was used as inocula which was subjected to commercial extracts of quebracho, oak and grape tannins at 10 doses and added to the incubation substrate (a total mixed ration based on alfalfa hay and concentrates, with $27 \%$ of starch and a F:C ratio of 40:60). Three combinations were selected out of 10 . The first combination selected contained $1.7 \%$ oak $+0.85 \%$ grape which showed positive effect by reducing methane production along with ammonical nitrogen concentration. The second combination contained $1.13 \%$ quebracho + $1.13 \%$ oak $+0.57 \%$ grape which showed reduction in methane and ammonical - N concentration along with increased propionate concentration. However there was reduction in NDF digestibility which could be one of the primary reasons for reduced methane production. However Combination 3 which consisted: $0.57 \%$ quebracho $+2.27 \%$ oak + $0.28 \%$ grape. It reduced gas and methane productions, ammonia-N concentration, molar proportion of minor VFA, and the A/P ratio. This was the treatment with the strongest effect on NH3-N concentration (-22\%). It also increased molar proportions of propionate and acetate, and it did not exert non-desirable effects on the in vitro ruminal fermentation parameters that were investigated.

Piñeiro-Vázquez et al., (2018) used respiration chambers to assess the effect of increasing amount of Leucaena leucocephala $(0 \%, 20 \%, 40 \%, 60 \%$ and $80 \%)$ on different types of nutritional parameters including DMI, OMI, enteric methane production , protozoal population and ruminal fermentation on cross bred heifers. A linear decrease in methane production was observed with increased amount of tannin content however no changes inn rumianl protozoa population was observed. Inclusion of $80 \%$ of L. leucocephala in the diet of heifers fed lowquality tropical forages has the capacity to reduce up to $61.3 \%$ enteric methane emission without affecting DMI, OMI, and protozoa population in rumen liquor. Parthasarthi et al., 2018 evaluated in vitro and in vivo methane emissions from Deccani lamb rams fed with tanninferaous feeds. About 3.6\% increase in in vitro dry matter digestibility along with $3.2 \%$ reduction in methane emissions was observed in treatment group fed with horse gram tannins. These findings were also supported by in vivo studies. Iqbal et al., 
(2018) used various tannin containing substrates viz. Anarchal, amla, Baheda and rohitaka at four levels (0-3\%) on digestibility of nutrients and enteric methane production. . It was concluded that best results on digestibility of nutrients, VFA production, ME availability and in reducing $\mathrm{CH} 4$ production was given by Anarchal and Rohitaka supplemented @ 2\% of TMR with $\mathrm{R}: \mathrm{C}$ ratio of $65: 35$ on DM basis. Baruah et al., 2019 used Syzygium cumini (source of HT) and Machilus bombycina (source of CT), in 18 sheep divided into three groups control, T1 and T2. Results from the study did not reveal any adverse impact of hydrolyzable and condensed tannin-containing leaves on the dry matter $(\mathrm{g} / 100 \mathrm{~kg} \mathrm{BW})$ or digestible dry matter intake. The study confirmed a significant reduction in enteric methane emission $(\mathrm{g} / \mathrm{d})$ due to the supplementation. The methanogen numbers in test groups $T_{1}$ and $T_{2}$ were lower than those in the control; however, the rumen protozoal population $(\times 105 / \mathrm{mL})$ was adversely affected by Syzygium cumini. Hong et al., (2018) replaced Leucaena with Mimosa pigra as the supplement to water spinach reduced the DM intake, tended to increase the DM digestibility and $\mathrm{N}$ retention $(p=0.058$ and 0.075 ), improved the biological value of the $\mathrm{N}$ ( $\mathrm{N}$ retained as \% of $\mathrm{N}$ digested) and the feed conversion (DM intake/ $\mathrm{N}$ retention) and reduced the ratio of methane to carbon dioxide in expired breath. It is hypothesized that the improvements in performance traits ( $\mathrm{N}$ retention and DMI to $\mathrm{N}$ conversion ratio) when Mimosa pigra replaced Leucaena were the consequence of the greater rumen bypass characteristics of the protein in Mimosa pigra associated with the increase in energy metabolism efficiency as a consequence of the reduction in rumen methane.

In conclusion, tannins were previously considered as anti-nutritional factors due to their astringent properties leading to decreased Crude Protein digestibility.
However now they are considered as herbal feed additives as they at a controlled amount they have shown to decrease methane and increase nutrient digestibility. However amount of tannins to be provided so as to increase nutrient digestibility needs further investigation as there is very fine line between positive and negative effects of tannins. Effects produced in rumen not only depend upon amount of tannins but also upon physiological status of animals leading to variable amount of methane inhibition. Respiratory chambers being costly equipment making methane estimation difficult. Though tannins available in natural form are easily available yet industrial extracts of tannins are a costly affair to be used as agricultural by product in developing countries like India.

\section{References}

Aboagye, I. A., Oba, M., Koenig, K. M., Zhao, G. Y., and Beauchemin, K. A. 2019. Use of gallic acid and hydrolyzable tannins to reduce methane emission and nitrogen excretion in beef cattle fed a diet containing alfalfa silage. Journal of Animal Science, 97(5): 2230-44.

Baruah, L., Malik, P. K., Kolte, A. P., Goyal, P., Dhali, A., and Bhatta, R. 2019. Rumen methane amelioration in sheep using two selected tanniferous phytoleaves. Carbon Management, 1-10.

Beauchemin K A, Kreuzer M, O'mara F and McAllister T A. 2008. Nutritional management for enteric methane abatement: a review. Animal Production Science 48(2): 21-27.

Bhatta, R., Baruah, L., Saravanan, M., Suresh, K.P. andSampath, K.T. 2013. Effect of medicinal and aromatic plants on rumen fermentation, protozoa population and methanogenesis in vitro. Journal of Animal Physiology and Animal Nutrition 97: 446-56. 
Carulla, J.E., Kreuzer, M., Machmuller, A. and Hess, H.D. 2005. Supplementation of Acacia mearnsii tannins decreases methanogenesis and urinary nitrogen in forage-fed sheep. Australian Journal of Agriculture Research56:961-70.

Cheynier, V. 2012. Phenolic compounds: From plants to foods. Phytochemistry Reviews 2 11: 153-177.

De Jesus NZ, de Souza Falcão H, Gomes IF, de Almeida Leite TJ, de MoraisLimaGR and Barbosa-Filho J Metal. 2012. Tannins, peptic ulcers and related mechanisms. International Journal of Molecular Science 13: 3203-28.

Doran-Browne, N., Behrendt, R., Kingwell, R. and Eckard, R. 2015. Modelling the potential of birds foot trefoil (Lotus corniculatus) to reduce methane emissions and increase production on wool and prime lamb farm enterprises. Animal Production Science55: $1097-$ 1105

Hanley, T.A., Robbins, C.T., Hagerman, A.E. and McArthur, C. 1992. Predicting digestible protein and digestible dry matter in tannin containing forages consumed by ruminants. Ecology. 73: 537-41

Hassanat, F. and Benchaar, C. 2013. Assessment of the effect of condensed (acacia and quebracho) and hydrolysable (chestnut and valonea) tannins on rumen fermentation and methane production in vitro. Journal of the Science of Food and Agricuture93:332-39.

Hatew, B., Carbonero, C.H., Stringano, E., Sales, L.F., Smith, L.M.J., MuellerHarvey, I., Hendriks, W.H. and Pellikaan, W.F. 2015. Diversity of condensed tannin structures affects rumen in vitro methane production in sainfoin (Onobrychis viciifolia) accessions. Grass Forage Science 70: 474-90.
Hong, N. T. T., Trang, N. T. N., Khang, D. N. and Preston, T. R. 2018. Supplementing water spinach (Ipomoea aquatica) with foliage of Mimosa pigra or Leucaena leucocephala and coconut oil; effects on $\mathrm{N}$ retention and enteric methane emissions in growing goats. Livestock Research for Rural Development, 30 .

Houghton J T, Ding Y D J G, Griggs D J, Noguer M, van der Linden P J, Dai X and Johnson C. A. 2001. Climate Change 2001: the Scientific Basis. The Press Syndicate of the University of Cambridge.

Hill, J., McSweeney, C., Wright, A.D., Bishop-Hurley, G. and Kalantar-Zadeh, K. 2016. Measuring Methane Production from Ruminants. Trends of Biotechnology. 34:26-35

Jayanegara, A., Leiber, F. and Kreuzer, M. 2012. Meta-analysis of the relationship between dietary tannin level and methane formation in ruminants from in vivo and in vitro experiments. Journal of Animal Physiology and Animal Nutrition 96: 365-75.

Johnson, K.A. and Johnson D.E. 1995. Methane emissions from cattle. Journal of Animal Sciences. 73: 2483-92

Lamy, E., Pinheiro, C., Rodrigues, L., Capelae Silva, F., Lopes, O.S. and Tavares, S. et al., 2016. Determinants of Tannin-Rich Food and Beverage Consumption: Oral Perception vs. Psychosocial Aspects. In: Combs CA (ed). Tannins: Biochemistry, Food Sources and Nutritional Properties. Nova Science Publishers Inc: New York, USA, pp. 29-58

Makkar H P S. 2003. Effects and fate of tannins in ruminant animals, adaptation to tannins, and strategies to overcome detrimental effects of feeding tanninrich feeds. Small Ruminant Research 49(3): 241-56. 
Mezzomo, R., Paulino, P. V. R., Barbosa, M. M., Martins, T. S., Pereira, L. G. R., Silva, J. C. and Serão, N. V. 2018. Protein dietary efficiency and methane emission in cattle fed soybean meal treated with tannins. Animal Production Science, 58(12): 2233-41.

Min, B.R., Barry, T.N., Attwood, G.T. and McNabb, W.C. 2003. The effect of condensed tannins on the nutrition and health of ruminants fed fresh temperate forages: A review. Animal Feed Science and Technology.106: 3-19.

Molina-Botero, I. C., Arroyave-Jaramillo, J., Valencia-Salazar, S., Barahona-Rosales, R., Aguilar-Pérez, C. F., Burgos, A. A. and $\mathrm{Ku}-$ Vera, J. C. 2019. Effects of tannins and saponins contained in foliage of Gliricidia sepium and pods of Enterolobium cyclocarpum on fermentation, methane emissions and rumen microbial population in crossbred heifers. Animal feed science and technology, 251: 1-11.

Moreira, G.D., Lima, P.D.T., Borges, B.O., Primavesi, O., Longo, C., McManus, C., Abdalla, A. And Louvandini, H. 2013. Tropical tanniniferous legumes used as an option to mitigate sheep enteric methane emission. Tropical Animal Health and Production 45: 879-82.

Mueller-Harvey, I. 2006. Unravelling the conundrum of tannins in animal nutrition and health. Journal of the Science Food and Agriculture.86: 2010-37.

Naumann, H.D., Tedeschi, L.O., Muir, J.P., Lambert, B.D. and Kothmann, M.M .2013. Effect of molecular weight of condensed tannins from warm-season perennial legumes on ruminal methane production in vitro. Biochemical Systematics and Ecology 50: 154-162.

Naumann, H. D., Tedeschi, L.O., Zeller, W. E. And Huntley, N.F. 2017. The role of condensed tannins in ruminant animal production: Advances, limitations and future directions. Revista Brasileria de Zootecnia. 46: 929-49.

O'Mara F P. 2011. The significance of livestock as a contributor to global greenhouse gas emissions today and in the near future. Animal Feed Science and Technology 166: 7-15.

Parthasarathi, T., Chandra, A. S., Ramana, D. B. V. and Raju, J. 2018. Effect of feeding tanniferous diets on methane emissions in sheep. Cellulose. 33(42.93): 11-71.

Pellikaan, W. F., Stringano, E., Leenaars, J., Bongers, D. J. G. M., VanLaar-van Schuppen, S., Plant, J. and MuellerHarvey, I. 2011. Evaluating effects of tannins on extent and rate of in vitro gas and $\mathrm{CH}_{4}$ production using an automated pressure evaluation system (APES). Animal Feed Science and Technology. 166-167: 377-390.

Piñeiro-Vázquez, A. T., Canul-Solis, J. R., Jiménez-Ferrer, G. O., Alayón-Gamboa, J. A., Chay-Canul, A. J., Ayala-Burgos, A. J. And Ku-Vera, J. C. 2018. Effect of condensed tannins from Leucaena leucocephala on rumen fermentation, methane production and population of rumen protozoa in heifers fed lowquality forage. Asian-Australasian journal of animal sciences, 31(11): 1738.

Ramirez-Restrepo, C.A.; Barry, T.N. 2005. Alternative temperate forages containing secondary compounds for improving sustainable productivity in grazing ruminants. Animal Feed Science and Technology, 120:179-201.

Robbins, C. T., Mole, S., Hagerman, A. E., and Hanley, T. A. 1987. Role of tannins in defending plants against ruminants: reduction in dry matter digestion. Ecology. 68(6): 1606-15.

Rochfort, S., Parker, A.J. and Dunshea, F.R. 2008. Plant bioactives for ruminant 
health and productivity. Phytochemistry. 69: 299-322.

Russell, J.B. and Wallace, R. J. 1997. Energy-yielding and energy-consuming reactions. In. The Rumen Microbial Ecosystem, Hobson PN, Stewart CS, editors. 2nd ed. London: Blackie Academic \& Professional. pp. 246-82.

Singh, I., Hundal, J. S., Wadhwa, M., and Lamba, J. S. 2018. Assessment of potential of some tannins and saponins containing herbs on digestibility of nutrients, fermentation kinetics and enteric methane production under different feeding systems: An in vitro study. Indian Journal of Animal Sciences. 88(4): 443-52.

Smeriglio, A., Barreca, D., Bellocco, E., and Trombetta, D. 2017. Proanthocyanidins and hydrolysable tannins: occurrence, dietary intake and pharmacological effects. British journal of pharmacology. 174(11): 1244-62.

Stewart, E. K., Villalba, J. J. and Rood, K. A. 2018. Environmental and Animal Benefits when Beef Cattle Consume Condensed and Hydrolysable Tannins. Tiemann, T. T., Lascano, C. E., Wettstein, H.
R., Mayer, A.C., Kreuzer, M. And Hess, H.D. 2008. Effect of the tropical tanninrich shrub legumes Calliandra calothyrsus and Flemingia macrophylla on methane emission and nitrogen and energy balance in growing lambs. Animal. 2(5):790-799.

Toral, P. G., Hervás, G., Belenguer, Á., Árturo-Schaan, M., Mendoza, A. G., Andrieu, D., and Frutos, P. 2019. Use of combinations of commercial extracts from quebracho, oak and grape tannins to modulate in vitro ruminal fermentation.

Wallace, R. J., McEwan, N. R., McIntosh, F. M., Teferedegne, B. and Newbold, C. J. 2002. Natural products as manipulators of rumen fermentation. Asian Australasian Journal of Animal Sciences 15(10): 1458-68

Woodward, S.I., Waghorn, G.C., Ulyatt, M. J. And Lassey, K.R. 2001. Early indications that feeding Lotus will reduce methane emissions from ruminants. In-Proceedings of New Zealand Society of Animal Production. 61: 23-26.

\section{How to cite this article:}

Prabhjot Kaur Sidhu and Anant Simran Singh. 2019. Effect of Tannin Containing Herbal Feed Additives on Ruminal Nutrient Utilization and Methane Mitigation - A Review. Int.J.Curr.Microbiol.App.Sci. 8(12): 2792-2801. doi: https://doi.org/10.20546/ijcmas.2019.812.327 